UDC 81-2

DOI https://doi.org/10.32447/2663-340X-2021-9.32

\title{
MIRRORING OF AESTHETIC VIEWS IN OSCAR WILDE'S FAIRY-TALE IMAGES
}

\author{
Shostak Uliana \\ Candidate of Psychological Sciences, \\ Assistant Professor at the Department of Foreign Philology and Translation \\ Vinnytsia Institute of Trade and Economics \\ of Kyiv National University of Trade and Economics \\ Str. Pirogova, 99A/5, Vinnytsia, Ukraine
}

\author{
Tkachuk Tetiana \\ Candidate of Philological Sciences, \\ Associate Professor at the Department of Foreign Philology and Translation \\ Vinnytsia Institute of Trade and Economics \\ of Kyiv National University of Trade and Economics \\ Str. Pirogova, 99A/5, Vinnytsia, Ukraine \\ Paslavka Inha \\ Senior Lecturer at the Department of Foreign Philology and Translation \\ Vinnytsia Institute of Trade and Economics \\ of Kyiv National University of Trade and Economics \\ Str. Pirogova, 99A/5, Vinnytsia, Ukraine
}

\begin{abstract}
The article analyses the formation, confrontation of Oscar Wilde's aesthetic views and mirroring them in his works. The analysis of biographical stages of life, critical literature and literary works of $O$. Wilde proved that the real confrontation of moral views took place but didn't find its theoretic and practical justification. Three major aspects of Wildean literary work serve as handles for this research examination. They are the Wildean interpretation of theory, Wilde's literary technique and philosophical assertion of masks and poses. Additionally, this study takes into account the overall critical history and personal biography of Wilde. Finally, the article asserts that Wilde's constructed his aesthetic views, which were multiessenced and, therefore, in direct conflict with the traditional Western notion of Aestheticism. The aim of the research is to reveal and prove the confrontation of moral views in the society of the certain epoch and artist's morals taking into account the certain epoch's stereotypes and believes. The work focuses attention on the following issues: the contradiction between Wilde's Aesthetic views: society and moral themes in fairy tales in general and in "The Young King" in particular; the problem of the relationship between the character and the society in the fairy tale "The Young King"; Narcissism in the nature of the Star Child. The research adopts historico-biographical approach to analyse the moral themes in Wilde's fairy tales. The main problems of O. Wilde's fairy tales are: the problem of self-sacrifice; the problem of the relationship between the characters and the society. The essence of the problem is that the outer and inner worlds are not always identical, but fate puts everything in its place. O. Wilde's tales represent both the most organic embodiment of the aesthetic ideas of the writer, and the most categorical objections to them.
\end{abstract}

Key words: aesthetic views, character, confrontation, fairy-tale, image, mirroring, Oscar Wild

Introduction. Critical analysis and historical research of the life and work of Oscar Wilde is still being controversial. It is nor only because of Wilde's individuality who is treated as an intentionally elusive artist, but also his milieu, the fin de siecle. It was the time of significant transition in the literary tradition of British writers. A study of any writer during this transitional time period immediately creates problems for the critic. When a writer is examined who is treated as a mythologized, flamboyant, that who relished misunderstanding, the already problematic nature of literary study is increased. However, not only the problems are accumulated but also the possibilities. This intriguing situation leads the situation where Wilde would have advocated the position of 
confronting an endless number of creations. The division between the nineteenth century and the twentieth century in terms of literary sensibility is extremely problematic and, consequently, identity issues derive out of this confusion. The rapid emergence of new ideas, technologies during this transitional period leaves the nature of identity, especially literary identity, open for numerous debates. Identity issues in general and aesthetic views in particular are especially significant for Wilde. Wilde's construction of his aesthetics views are fundamentally focused on creating a self that is multiessenced, a self that is complex, and a self that holds growth as perhaps its ultimate moral achievement. Wilde's language is used to describe this ideal construction of ideal self finds its realization in fairy-tale images. As Gilbert states in "The Critic as Artist": "It is sometimes said that the tragedy of an artist's life is that he cannot realize his ideal. But the true tragedy that dogs the steps of most artists is that they realize their ideal too absolutely. For, when the ideal is realized, it is robbed of its wonder and its mystery [2, 568]. Creating the ideal and keeping it unattainable is the masterpiece, the ultimate artistic achievement for Wilde.

Oscar Wilde is known as a famous playwright and aesthete of the late Victorian society. His works include: plays, novels and essays and he had published nine fairy tales in two volumes: Happy Prince and Other Tales and A House of Pomegranates. According to the study Wilde's fairy tales contain various moral themes. It should be noted that moral themes contradict social and Wilde's Aesthetic views.

The aim of the research is to reveal and prove the confrontation of moral views in the society of the certain epoch and artist's morals taking into account the certain epoch's stereotypes and believes. The work focuses attention on the following issues: the contradiction between Wilde's Aesthetic views: society and moral themes in fairy tales in general and in "The Young King" in particular; the problem of the relationship between the character and the society in the fairy tale "The Young King"; Narcissism in the nature of the Star Child.

Theoretical framework. The philosophical grounds of Aestheticism were formulated in the XVIII th century by Immanuel Kant, who proposed the autonomy of art. Art for its sake, its essence or beauty. Aestheticism was supported in Germany by J. W. von Goethe and in England by Samuel Taylor Coleridge and Thomas Carlyle.

B. Constant first used the phrase l'art pour l'art ("art for art," or "art for art's sake") in 1804;
Victor Cousin popularized the moto which became a catch-phrase for Aestheticism in the 1890s. The French writers (Théophile Gautier, Charles-Pierre Baudelaire) also contributed to the development of this movement.

Oscar Wilde was not the inventor of Aestheticism, but he was a dramatic leader, who promoted the movement at the end of the XIXth century. Wilde was strongly influenced being a college student by Algernon Charles Swinburne and the American writer Edgar Allan Poe's works.

Research findings. Wilde was an important representative of Aestheticism, an art movement popular at the end of the $19^{\text {th }}$ century in Britain. "Art for art's sake" is one of Aestheticism's famous slogans. Also, Wilde said, "No artist has ethical sympathies. An ethical sympathy in an artist is an unpardonable mannerism of style" $(2,3)$. "Any element of morals or implied reference to a standard of good or evil in art is often a sign of a certain incompleteness of vision, often a note of discord in the harmony of an imaginative creation; for all good works aim at a purely artistic effect" (2). Wilde believed that art is called for artists' imagination and creativity. Art should not be bound by other things, which could damage art. The artists' task was not to prove anything but to reveal art. Although Wilde objected to relate morality to literary works, in his fairy tales, moral themes are obvious, which contradicts his previous comments on literary works. Actually, not only his fairy tales, but also his novel, plays and artistic views consist of contradictions. Before the 1950s, most of the studies of Oscar Wilde focused on his biography, scandal and trial (Th. A. Mikolyzk "Oscar Wilde: an Annotated Bibliogrphy" [8], 1993; Robert Harborough Sherard "Life of O. Wilde" [11], "The Real Oscar Wilde", Frank Harris "Oscar Wilde: his Life and Confession" [4]), which "lack depth on his thoughts and craeations" [14, 8]. Later, people paid more attention to his artistic views and literary works (Epifanio Jr San Juan "The Art of Oscar Wilde" [10] which was based on textual analysis, 1967; Richard Ellamn [1] with modern critical approaches to study Wilde's works). The studies on his contradictions had begun as soon as his works were published (Regenia Gagnier's "Idylls of the Marketplace: O.W. and the Victorian Public" and "Critical Essays on Oscar Wilde" [2]; Curtis Marez's "The Other Addict: Reflections on Colonialism and Oscar Wilde's Opium Smoke Screen" [7]). At the end of the twentieth century, the centenary of Wilde's death, an increasing number of books, articles and periodicals about Wilde were published [14, 9-10]. But the number of critical issues didn't show the retrospective 
picture of the confrontation of views in O.Wilde's life and literary works. The analysis of biographical stages of life, critical literature and literary works of $\mathrm{O}$. Wilde proved that the real confrontations of morals views took place, but didn't find its theoretic and practical justification.

This research adopts historico-biographical approach to analyze the moral themes in Wilde's fairy tales. Historical-biographical approach is one of the traditional critical approaches to literature. "This approach sees a literary work chiefly, if not exclusively, as a reflection of its author's life and times or the life and times of the characters in the work" [3, 22]. While analyzing literary works, textual criticism should be used to establish an authentic text. Next, to analyze the literary works, the first step is to ascertain the literary genre, because "different literary genres are judged according to different standards" [3,28].

The moral themes in Wilde's fairy tales are diverse. According to Professor Jack Zipes, "Happy Prince and Other Tales" is "an anthology about British civilization and its discontents" $(1,211)$. "The Happy Prince" and "The Nightingale and The Rose" express Wilde's idea that the society is not able to appreciate the noble role of artists. "The Devoted Friend" and "The Remarkable Rocket" are about people's unawareness of ruthlessness. Wilde's another volume of fairy tales, A House of Pomegranates, "explores the connection between love, art and sacrifice" $(1,212)$. Apart from Professor Jack Zipes's researches, some other researches focus on the suffering, deaths of characters and charity.

Wilde's Aesthetic views were deeply influenced by the theories of his mentors: John Pentland Mahaffy, John Ruskin and Walter Pater. The theories of his three teachers are different. What is more, Ruskin's theories are opposite to Pater's theories, which is the root of Wilde's contradiction.

In many of Wilde's essays like "The English Renaissance of Art", "The Decay of Lying" and the preface to "The Picture of Dorian Gray", Wilde expressed his Aesthetic views that aim at a purely artistic effect and art should not be bound by morality.

The fairy tale is a genre "known for its moralistic nature" [12], which contradicts Wilde's claims that art should not contain any element of morality. During 1865 to 1900 , some famous writers like John Ruskin and Lewis Carroll made contribution to the development of fairy tales. In 1889, Wilde reviewed William B. Yeats's "Fairy and Folk Tales of the Irish Peasantry" (1) and showed great interest in this genre. Wilde's wife also published some children stories. His mother edited two books on Irish Folklore. Also, in some of his tales, Wilde unsettled the traditional structure of fairy tales in order to satirize some social phenomenon. For example, "The Devoted Friend" is quite similar to Hans Christian Andersen's "Little Claus and Big Claus". However, Wilde's tale ends with the protagonist's death while Andersen's tale ends with the antagonist's death.

O. Wilde's tales, like all his works, are very multifaceted, and they raise many problems, the most expressive are: the problem of self-sacrifice; the problem of the ratio of the beauty of the outer and inner (Narcissism); the problem of the relationship between the characters and the world/ society. The problem of cruel reality in O. Wilde's work is a special one. It is most clearly shown in fairy tales: "The Young King", "The Loyal Friend", "The Infanta's Birthday".

In the fairy tale "The Young King" the main character - the Young King is shown at the beginning of the fairy tale as a person who feels uncomfortable in the real world: "He lay ... looking before him with frightening eyes, like a swarthy forest fauna or a young beast caught in a trap set by hunters" (1).

Previously, he was a simple shepherd, enjoying a carefree life, and did not know his origin. But, when trapped in a castle, the King is fascinated by the beauty and luxury around, until in his dream he comes to understand the price, and the price is the life of many and many people. Young King abandons fine clothes: "Take it away and hide it from me. Although today is my coronation day, I will not accept it. For the garment is woven on the loom of Sorrow with the white hands of Pain. In the heart of the ruby is blood, and in the heart of pearls-death" (1).

But others do not understand the King: "Truly he has lost his mind... And what about the lives of those who work for us? And do you refrain from bread until you see a plowman, and from wine, until you speak the words to the husbandman?" they speak with court astonishment" "(1).

They break into the door of the church to kill the King who did not accept them. Conflict reaches its climax, but the King finds spiritual harmony. Higher powers reward him: "And here through the stained-glass windows sunlight flooded upon him, and the rays of the sun weaved around him a better choice than they did for his luxury. ... He stood in the royal favor and a mysterious marvelous light poured down from the crystal faces of the pornos. ... On his knees, the bishop reverently says, "He who is above me, has crowned you!" "(1)

In the fairy tale, the main conflict is complemented by a number of accompanying 
conflict situations: the contradiction of sincerity and lies, dreams and harsh reality, natural life and court, indifference and humanity, splendor and cruelty, the splendor of the yard and poverty.

Higher powers resolve this conflict. This is a kind of conclusion. Its essence is that, the inner world of characters cannot always find understanding in the real world, but there is a different world - a world of harmony, justice, and it always stands up for the pure, sincere souls of characters.

In this tale, Christianity and the Aesthetic life blend perfectly. The young King indulged himself in objects of art like a disciple of Pater's advices: be in a state of "ecstasy", "the poetic passion, the desire of beauty, the love of art for its own sake" [9]. Nevertheless, the young King's nature developed. He became aware of his people's life. When he was finally on the altar in rags, "the sunbeams wove round him a tissued robe that was fairer than the robe that had been fashioned for his pleasure" $(1,96)$. "Whiter than fine pearls were the lilies...Redder than male rubies were the roses" $(1,96)$. The Bishop said, "A greater than I hath crowned thee" $(1,96)$, which implied that God had crowned the young King. Thus, the young King had entered a new Aesthetic world where "the pure and indescribably beautiful" Christianity is "the highest form of Aestheticism" [9].

The Narcissism in the nature of the Star Child

O. Wilde considers the problem of correlation of external and internal beauty in many of his tales under different angles. In his view, "the basis of morality is an aesthetic sense" (1). The tale "The Star Child" is interesting because the writer consistently upholds the principle of continuity of the external and internal beauty of a man. The main conflict underlying the story of this fairy tale is the collision of beauty and ugliness in its two hypotheses: external and internal content. At the beginning of the fairy tale the main character - the Star Child appears in front of us surprisingly beautiful: " $E v$ e r y year he became more and more beautiful and the inhabitants of the village marveled at his beauty. His face was white and delicate, as if worn from ivory, and gold. his curls were like the petals of a daffodil, and his lips were like the petals of a bright red rose, and his eyes were like violets reflected in the clear water of a stream. "(1).

The beauty that gave limitless power brought him only evil. He grew violent and selfish. Mental anger, immense pride, inability to love whoever he is and, above all, his mother - the features of spiritual ugliness, reflect on his face and make him a freak from the outside: "He went to the reservoir and looked at him, but what, he saw! He became like a frog, and his body was covered with scales like a viper." (1).

In the fairy tale "The Star Child" the ratio of inner and outer beauty is clearly shown. Outside, the Star Child is handsome, but his inner world is ugly. As the punishment, they take away the most valuable - the beauty.

Taking Keats' aesthetic formula that beauty is the only truth, O. Wilde emphasizes in his fairy tales that the outer beauty must necessarily correspond to the inner beauty. And he dreams of a time when "there will be no more people living in stinking cubes dressed in stinking rags ... When hundreds of thousands of unemployed are driven to the most outrageous poverty, they will not be trampled on the streets. .. when every member of society is a participant in the common prosperity and well-being." (1).

Conclusions. Oscar Wilde is one of the most paradoxical minds in human history. All his life he resisted the peace of everything official. He opposed public opinion. All the trivial annoyed him, all the ugly repelled him. The only refuge from vulgarity, boredom and monotony $\mathrm{O}$. Wilde saw in Art. He wrote the word in the capital letter.

For Wilde, constructing a multiessenced self through aesthetic views is achieved through a variety of means including philosophic proportions. Also, because of Wilde's individuality, his construction of the aesthetic views is rife with tensions because of personal, societal, and intellectual constraints and expectations. As he is known as a serious and talented writer, his construction of views takes on technical, literary aspects style of depiction. Because he loved society and its material comforts, this construction assumes a social role that creates, and leads. Wilde demonstrates the aesthetic superiority of constructing a multiessenced self over accepting a given, natural single-essenced existence through his work.

The tales of $\mathrm{O}$. Wilde are multifaceted and many problems are raised in them. The main ones are: the problem of self-sacrifice; the problem of the relationship between the characters and the society. The essence of this problem is that often the inner world of characters - the world of beautiful illusions cannot always find understanding in the surrounding, real world; the problem of the ratio of the beauty of the outer and inner. The problem is that the outer and inner worlds are not always identical, but fate puts everything in its place. The peculiarity of $O$. Wilde's tales is both the most organic embodiment of the aesthetic ideas of the writer, and the most categorical denial of them. 
1. Ellamm, R. (1988). Oscar Wilde. Vintage Books.

\title{
REFERENCES
}

2. Gagnier, R. (1991). Critical Essays on Oscar Wilde. New York: Hall.

3. Guerin, W.L. (2004). A Handbook of Critical Approaches to Literature. Beijing: Foreign Language Teaching and Research Press.

4. Harris, F. (2017). His Life and Confession.Create Space Ind.Publishing Platform.

5. Landow, G.P. (2012). Aesthetes, Decadents, and the Idea of Art for Art's Sake. Rhode Island: Brown University.

6. Landow, G.P. (2005). Ruskin's Theories Beauty - Vital Beauty. Rhode Island: Brown University.

7. Marez, C. (1997). The Other Addict: Reflections on Colonialism and Oscar Wilde's Opium Smoke Screen. ELH, Vol. 64, No. 1 (Spring, 1997), pp. 257-287.

8. Mikolyzk, Th.A. (1993). Oscar Wilde: an Annotated Bibliography. USA: Greenwood Press.

9. Nassaar, Ch.S. (2002). Pater in Wilde's The Happy Prince and Other Tales and A House of Pomegranates. Beirut: American University of Beirut.

10. San Juan, E. Jr. (1967). The Art of Oscar Wild. Princeton University Press: Princeton.

11. Sherard, R.H. (1906). The Life of O. Wilde. London.

12. Wijingaart, K. (2012). Oscar Wilde’s Essays and Fairy Tales: Aesthetic Morality. Utrecht, Netherlands: University of Utrecht.

13. Wong, R. (2008). Ruskin, Wilde, Satire, and the Birth of Aestheticism. Rhode Island: Brown University.

14. Zhong Ya. (2011). Aesthetical Orientation of Oscar Wilde's Novels and Plays. Shanghai: Shanghai International Studies University.

\section{ILLUSTRATIVE MATERIAL}

1. Wilde, O. (2008). Complete Fairy Tales of Oscar Wilde. New York: Penguin Group (USA) Inc..

2. Wilde, O. (2003). The Decay of Lying, Intentions. The Gutenberg Project e-Book.

3. Wilde, O. (2013). The English Renaissance of Art, Essays and Lectures. The Gutenberg Project e-Book.

\section{ВІДДЗЕРКАЛЕННЯ ЕСТЕТИЧНИХ ПОГЛЯДІВ В ХУДОЖНІХ ОБРАЗАХ КАЗОК ОСКАРА УАЙЛЬДА}

\author{
Шостак Уляна \\ кандидат психологічних наук, \\ дочент кафедри іноземної філології та перекладу \\ Вінницького торговельно-економічного інституту \\ Київського національного торгово-економічного університету \\ вул. Пирогова, 99A / 5, Вінниця, Украӥна

\section{Ткачук Тетяна} \\ кандидат філологічних наук, \\ дочент кафедри іноземної філології та перекладу \\ Вінницького торговельно-економічного інституту \\ Київського начіонального торгово-економічного університету \\ вул. Пирогова, 99А / 5, Вінниця, Украӥна

\section{Паславка Інга} \\ старший викладач кафедри іноземної філології та перекладу \\ Вінницького торговельно-економічного інституту \\ Київського національного торгово-економічного університету \\ вул. Пирогова, $99 \mathrm{~A} /$ 5, Вінниця, Україна
}

У статті проаналізовано формування, протистояння естетичних поглядів Оскара Уайльда та відображення їх у його творах. Аналіз біографічних етапів життя, критичної літератури та літературних творів О. Уайльда довів, щзо справжне протистояння моральних поглядів мало місце, але не знайшло свого теоретичного та 
практичного виправдання. Три основні аспекти літературної творчості Оскара Уайльда служать засобами для иьього дослідження: аналіз його творчості, літературна техніка Оскара Уайльда та філософське трактування його естетичних поглядів. Крім иього, ие дослідження враховує загальну критичний аналіз та біографію Оскара Уайльда. У статті стверджується, щзо Уайльд будував свої естетичні погляди в прямому протиріччі з традиційним західним поняттям естетизму. Метою дослідження є виявлення та доведення протистояння моральних поглядів у суспільстві певної епохи та естетичних поглядів мития з урахуванням стереотипів та вірувань певної епохи. Дослідження зосереджує увагу на таких проблемах: суперечність між естетичними поглядами Уайльда: суспільство та моральна тематика в казках загалом та в "Молодий король" зокрема; проблема взаємовідносин персонажа та суспільства у казиі “Молодий король”; нариисизм у природі “Зоряна дитина”. Дослідження застосовує історико-біографічний підхід до аналізу моральних тем у казках Оскара Уайльда. Основними проблемами казок О. Уайльда є проблема самопожертви; проблема стосунків між героями та суспільством. Суть проблеми полягає в тому, що зовнішній і внутрішній світи не завжди ідентичні, але доля ставить все на свої місия. Казки О. Уайльда представляють як найбільш органічне втілення естетичних ідей письменника, так і найбільш категоричні заперечення проти них.

Ключові слова: естетичні погляди, образ, протистояння, казка, віддзеркалення поглядів, Оскар Уайльд. 